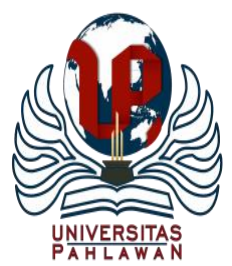

Jurnal Abdidas Volume 2 Nomor 3 Tahun 2021 Halaman 700-704

JURNAL ABDIDAS

http://abdidas.org/index.php/abdidas

\title{
Pelatihan Pengelolaan Website Perguruan Tinggi
}

\author{
Suryadi Syamsu ${ }^{1}$, Mashud ${ }^{2}$, Ahmad Zulvikar $S^{3}$ \\ Teknik Informatika, STMIK AKBA, Indonesia ${ }^{1,3}$ \\ Sistem Informasi, STMIK AKBA, Indonesia ${ }^{2}$ \\ E-mail : adi@akba.ac.id ${ }^{1}$, mashud@akba.ac.id ${ }^{2}$, ahmadulvikar18@mhs.akba.ac.id ${ }^{3}$
}

\begin{abstract}
Abstrak
Perkembangan teknologi informasi saat ini berkembang dengan cepat hampir sebagian besar dari kegiatan manusia memanfaatkan teknologi informasi. Perguruan tinggi juga tidak kalah bersaing, perguruan tinggi sedang dalam masa pengoptimalan penggunaan teknologi informasi. Website saat ini digunakan untuk berbagai kebutuhan mulai dari menjadi wajah digital bagi institusi resmi, seperti lembaga pemerintahan atau badan usaha dalam menghadapi masyarakat digital. Pelaksanaan kegiatan pengabdian masyarakat dilaksanakan pada 10 Februari 2021 di Sekolah Tinggi Ilmu Ekonomi LPI Makassar. Pelaksanaan kegiatan pengabdian masyarakat dilaksanakan dalam bentuk pelatihan. Adapun tujuan dari pengabdian ini adalah untuk memberikan pelatihan, pemahaman, dan pengetahuan kepada peserta, tentang pengelolaan website di perguruan tinggi. Dari kegiatan pengabdian masyarakat yang telah dilaksanakan maka dapat disimpulkan bahwa pelatihan ini dapat meningkatkan keterampilan dan kemampuan staf dan dosen dalam mengelolah website.
\end{abstract}

Kata kunci: pelatihan, perguruan tinggi, website

\section{Abstract}

The development of information technology is currently growing rapidly, almost most of human activities utilize information technology. Universities are also no less competitive, universities are in a period of optimizing the use of information technology. Websites are currently used for various needs ranging from being a digital face for official institutions such as government agencies or business entities in dealing with digital society. The implementation of community service activities will be carried out on February 10, 2021 at the LPI Makassar College of Economics. The implementation of community service activities is carried out in the form of training. The purpose of this service is to provide training, understanding, and knowledge to participants, regarding website management in universities. From the Community Service Activities that have been carried out, it can be concluded that this training can improve the skills and abilities of staff and lecturers in managing websites.

Keywords: training, college, website

Copyright (c) 2021 Suryadi Syamsu, Mashud, Ahmad Zulvikar S

$\triangle$ Corresponding author

Address : STMIK AKBA

ISSN 2721-9224 (Media Cetak)

Email : adi@akba.ac.id

ISSN 2721- 9216 (Media Online)

DOI : https://doi.org/10.31004/abdidas.v2i3.349 


\section{PENDAHULUAN}

Perkembangan teknologi informasi saat ini berkembang dengan cepat hampir sebagian besar dari kegiatan manusia memanfaatkan teknologi informasi. Perkembangan teknologi informasi memunculkan berbagai jenis kegiatan yang berbasis pada teknologi informasi, seperti $e$ government, e-bisnis, e-education dan sebagainya. Perguruan tinggi juga tidak kalah bersaing, perguruan tinggi sedang dalam masa pengoptimalan penggunaan internet dalam perkuliahaan baik itu pembelajaran di dalam kelas maupun diluar kelas (Nanda, Harahap, \& Manurung, 2017).

Fakta di atas membuktikan bahwa dunia pendidikan dituntut untuk dapat mengikuti perkembangan teknologi informasi. Perkembangan teknologi informasi yang begitu cepat ini secara otomatis menuntut peningkatan kualitas sumber daya tenaga pendidik dalam bidang teknologi informasi. Dengan internet dapat menunjang perkembangan perguruan tinggi menjadi terdepan dalam mewujudkan visi dan misi perguruan tinggi.

Website atau situs dapat diartikan sebagai kumpulan halaman yang menampilkan informasi data teks, dan data gambar diam atau gerak, data animasi, suara video dan atau gabungan dari semuanya, baik yang bersifat statis maupun dinamis yang membentuk satu rangkaian bangunan yang saling terkait di mana masing-masing dihubungkan dengan jaringan-jaringan halaman (hyperlink). Bersifat statis apabila isi informasi website tetap, jarang berubah, dan informasinya searah hanya dari pemilik website. Bersifat dinamis apabila isi informasi website selalu berubah-ubah, dan isi informasinya interaktif dua arah berasal dari pemilik serta penguna website (Gafur, 2017).

Website biasa digunakan untuk berbagai kepentingan. Mulai dari untuk menjadi sisi wajah digital bagi institusi resmi seperti lembaga pemerintahan atau badan usaha dalam menghadapi masyarakat pengguna jasa atau produknya, hingga untuk keperluan aktualisasi individu dalam bentuk personal blog. Instansi pemerintahan, mulai dari tingkat kementrian hingga ke tingkat desa (di Sumatera Barat lazim dikenal sebagai nagari) sudah banyak yang menyadari arti penting adanya website resmi instansi mereka dan berusaha memaksimalkan pemanfaatannya untuk meningkatkan kinerja layanan mereka kepada masyarakat (Arief, et al., 2017).

Sekolah Tinggi Ilmu Ekonomi LPI Makassar merupakan perguruan tinggi swasta yang juga terus mengikuti perkembangan teknolgi. Hal ini dapat dilihat dengan adanya website perguruan tinggi yang dikelola (https://stie-lpi.ac.id/). Adapun tujuan dari pengabdian ini adalah untuk memberikan pelatihan, pemahaman, dan pengetahuan kepada peserta, dalam hal ini Dosen dan Staf Sekolah Tinggi Ilmu Ekonomi LPI Makassar tentang pengelolaan website perguruan tinggi, sehingga memperoleh pengetahuan tentang penggunaan fitur-fitur, dan plug in yang telah disediakan. Sehingga menampilkan website yang menarik dan dapat memberikan informasiinformasi yang ter-update ke masyarakat umum. 
METODE

Pelaksanaan kegiatan pengabdian masyarakat dilaksanakan pada 10 Februari 2021. Kegiatan pengabdian masyarakat ini dilaksanakan di Kampus Sekolah Tinggi Ilmu Ekonomi LPI Makassar, yang lokasinya berada di Jalan Bung 32 Tamalanrea, Kota Makassar, Provinsi Sulawesi Selatan. Pelaksanaan pengabdian masyarakat ini dilakukan dalam beberapa langkah yang melibatkan metode berupa wawancara, penelitian pustaka, perancangan dan implementasi, diskusi dan pelatihan.

Tujuan akhir kegiatan ini adalah pelatihan pengelolaan web perguruan tinggi. Untuk mencapai tujuan tersebut, diperlukan tahapantahapan kegiatan pengabdian sebagai sebagai berikut.

1. Perancangan Kegiatan

Pembuatan bahan presentasi oleh pelaksana. Perancangan metode transfer of knowledge pengelolaan website oleh pemateri.

2. Persiapan

Tahapan selanjutnya adalah melakukan persiapan pelatihan meliputi jenis, materi, koordinasi dengan pihak perguruan tinggi dalam hal dengan Sekolah Tinggi Ilmu Ekonomi LPI Makassar dan hal-hal lain yang berhubungan dengan kegiatan pelatihan yang akan diselenggarakan.

3. Pelatihan

Kegiatan kunjungan dan pelatihan di Sekolah Tinggi Ilmu Ekonomi LPI Makassar tentang pengenalan dan pengelolaan web kepada staf, dosen dan pejabat struktural.
Evaluasi dilakukan terhadap hasil kegiatan pengabdian kepada masyarakat ini yang meliputi analisa kelebihan, kekurangan, hambatan dan peluang pengembangan.

\section{HASIL DAN PEMBAHASAN}

Adapun rangkaian pelaksanaan kegiatan pelatihan pengelolaan website perguruan tinggi, sehingga diharapkan para dosen dan staf memiliki pengetahuan dan keterampilan dalam mengelola website kampus serta melakukan pengembangan terhadap website tersebut. Peserta dalam hal ini dosen dan staf diberikan materi secara langsung dalam melakukan pengolahan website.

1. Pembukaan kegiatan pengabdian masyarakat, yang terdiri dari sambutan Ketua STIE LPI, dan memberikan arahan dan pedoman terhadap peserta dalam hal ini Dosen dan Staf STIE LPI.

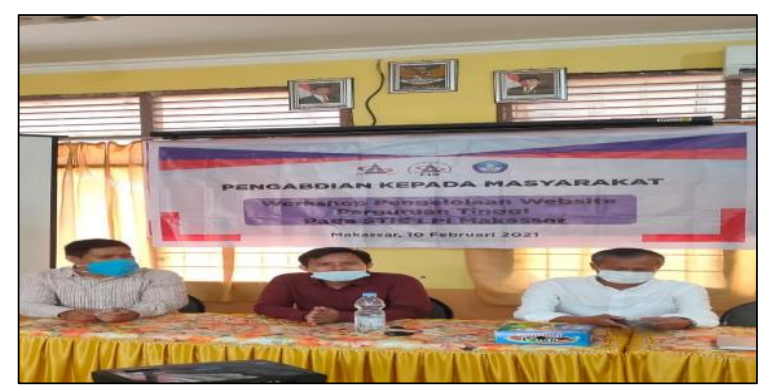

Gambar 1. Sambutan

2. Penyampaian materi yang langsung dibawakan oleh pemateri ke peserta, dengan cara memptraktikkan langsung cara pengolahan website profil kampus, dan cara menggunakan tools untuk tahap pengembangan website kedepannya. Adapun materinya yaitu pengaturan tata letak halaman website dan panduan pengisian konten berita. 


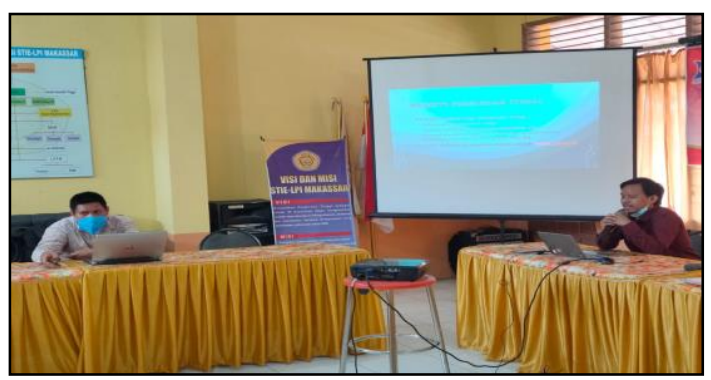

Gambar 2 . Penyampaian Materi Pengelohan Website

3. Tanya jawab, pada tahap ini peserta dalam hal ini staf dan dosen tanya jawab. Pada tahap ini peserta dalam hal ini Staf dan Dosen Sekolah Tinggi Ilmu Ekonomi LPI Makassar sangat antusias, dilihat dari beberapa dosen yang bertanya mengenai cara mengembangkan website, dan cara membuat tampilan website yang menarik.

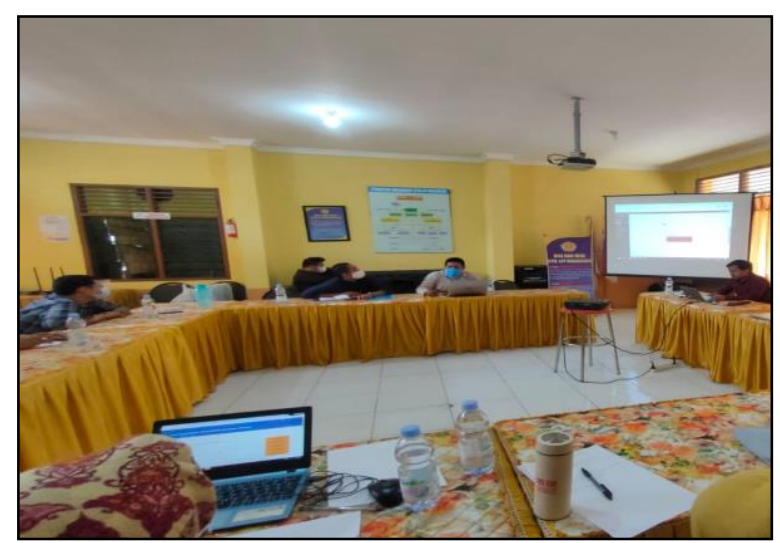

Gambar 3 Tanya Jawab Pemateri dan Peserta

4. Sebagai penutup pada kegiatan pengabdian masyarakat ini yaitu foto bersama dengan peserta.

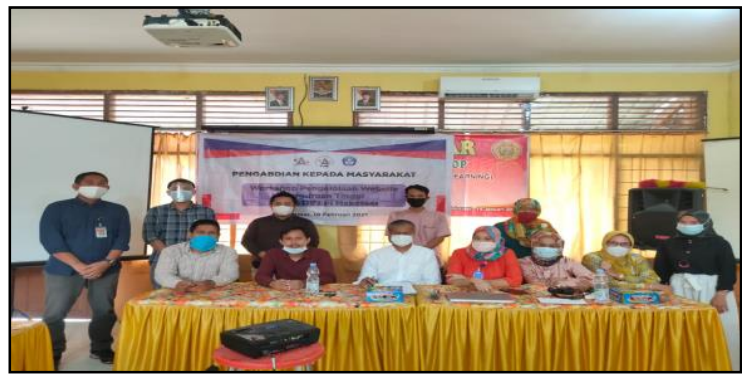

Gambar 4 Foto bersama Peserta

Berikut adalah evaluasi hasil kegiatan meliputi situasi pelaksanaan, analisa kelebihan, kekurangan, hambatan, peluang pengembangan, pelajaran apa yang dapat diambil dari hasil evaluasi.

1. Situasi Pelaksanaan:

Situasi pelaksanaan kegiatan pengabdian kepada masyarakat di Sekolah Tinggi Ilmu Ekonomi LPI Makassar berjalan baik, peserta menyimak materi dan aktif dalam sesi tanya jawab dan diskusi.

2. Kelebihan yang ditemukan saat pelaksanaan :

Kelebihan yang ditemukan saat kegiatan yaitu peserta diberi kesempatan untuk memberikan saran serta perbaikan yang dapat dilakukan untuk pengembangan website perguruan tinggi.

3. Kekurangan yang ditemukan saat pelaksanaan kegiatan:

Kekurangan yang dtemukan adalah saat peserta mengajukan pertanyaan waktu yang disediakan kurang untuk memenuhi semua pertanyaan.

4. Peluang pengembangan:

Peluang pengembangan kegiatan pengabdian kepada masyarakat dan kerjasama antara Sekolah Tinggi Ilmu 
Ekonomi LPI Makassar dengan STMIK AKBA.

5. Tercapainya Sasaran

Dalam kegiatan pengabdian masyarakat ini yang menjadi sasaran adalah Dosen dan Staf Sekolah Tinggi Ilmu Ekonomi LPI Makassar pelatihan pada 10 Februari 2021 diikuti oleh dosen dan staf.

6. Tercapainya Manfaat

Pelaksanaan kegiatan pengabdian masyarakat meningkatkan keterampilan dan kemampuan staf dan dosen dalam mengelolah website.

\section{SIMPULAN}

Dari kegiatan pengabdian masyarakat yang telah dilaksanakan maka dapat disimpulkan bahwa pelatihan ini dapat meningkatkan keterampilan dan kemampuan staf dan dosen dalam mengelolah website.

\section{UCAPAN TERIMA KASIH}

Pelaksana pengabdian masyarakat mengucapkan terima kasih kepada Pusat Penelitian dan Pengabdian Masyarakat STMIK AKBA atas bantuan dana dan motivasi dalam melaksanakan pengabdian dan kepada Pihak Sekolah Tinggi Ilmu Ekonomi LPI Makassar yang telah bersedia menjadi mitra dalam pengabdian masyarakat ini.

\section{DAFTAR PUSTAKA}

Arief, L., Derisma, Yolanda, D., Putri, N., Kasoep, W., \& Putri, R. E. (2017). Pengembangan Dan Pelatihan Pengelolaan Website Berbasis Content Management System (Cms) Untuk Pemerintahan Nagari Dan Badan Usaha Milik Nagari (BUMNag) Kanagarian Durian
Gadang . Padang: program studi sistem komputer, fakultas teknologi informasi, universitas andalas .

Gafur, A. (2017). Perancangan Website Pada Program Studi Teknik Sipil Fakultas Teknik Dan Ilmu Komputer Universitas Islam Indargiri. Jurnal SISTEMASI, 25 - 32.

Nanda, E. A., Harahap, F., \& Manurung, B. (2017). Rancang Bangun Website Pembelajaran Pada Perguruan Tinggi (Studi Kasus : Mata Kuliah Kultur Jaringan Pendidikan Biologi Universitas Negeri Medan). Prosiding Seminar Nasional III Biologi dan Pembelajarannya (pp. 643-656). Medan: Universitas Negeri Medan. 